While the actual curative remedles are small in number, the treatment covers a variety of ob. fects to be attained in various other ways. The patient must be made comfortable even in hope. less diseases. Watch closely and you can obviate many errors of attendants and nurses. All sue. ferings, even of only a temporary nature, must be alleviated. And agaln the physician is and ought to be his patient's protector. Because the quarantine laws often enforce harsh measures against a stricken patient, therefore the doctor shsuld see to it that his patient receives respect, charity and kindness from the health officer. Gentlemen, do not for a moment let the joen rest in your minds that it is a sacrifice to be an every. day practitloner of medicine, but on the contrary. it should be, and is, your greatest pleas. ure.

\section{THE WORK OF A COUNTY HEALTH OFFICER IN ALABAMA.*}

By R. M. Davis, Mr. D., Health Offlcer Lauderdale County, Ala., F'orence, Ala.

"The work of a County Health Officer in this State." What is it? The answers to thls ques. tion necessarily vary, depending upon several things. For instance, asked twenty years ago and answered as the work was then done, the answer would differ materially from a response given today.

Ask it of a Health Officer who has accepted the position merely for the loaves and fishes, notwithstanding their paucity, your answer would not accord with the one made by a man who bas taken up the work impressed with it as a vital need, impressed by his respongibility, and inspired by the good he can accomplish in rendering to h/s county in well-planned and well-directed work service far In excess of any material gain that might accrue therefrom.

Twenty years ago the lalty knew little of this work and if by chance it came to their notice they considered it lightly and looked upon it as a sinecure for scheming doctors and politisinns who were entirely interested in self:

- The majority of physiclans felt that it' was a work that belonged wholly to the Health Officer and few took interest in the officer or his work. The average Health Officer manlfested iittle en-

- Read at the annual meeting of the Alabama Medical Association, Moblle, April 17, 1913. thusiasm. He was more concerned about the amount the Board of Revenue would deign to pay.

Incidentally he would register at his lelsure and in rather a careless way whatever deaths or blrths were brought to his office. It smallpox or yellow fever chanced to break out in his county, which dfd not happen often during hls brlet and uncertain tenure of office, he would bestir himself and institute a shotgun quarantine and raccinate wnom he could. The sanitary conditions of his surroundings did not concern him much, and if the old axiom, "An ounce of prevention is worth a pound of cure," fioated across his mental vision it was only in a hazy way, a thing that belonged to posterity, a Utopian aftair anywav. In short. during the absence of the above-named diseases, he drew his quarterly stipend and bemeaned the County Commissioners for not paying more. This was hls most constant and arduous labor.

Understand, please, such as these were the rule, but occasionally we met with the exception. In Autanga County, one of the earllest and most efficient Health Officers was Dr. Samuel P. Smith, who devoted time, talent and energy to his work, and today in that county records made a quarter of a century ago bear testimony to this man's fidelity and to his conviction that the work was of Inestimable value.

Dr. Cochrane, the ploneer In this work, labored long and arduously to arouse the doctors to the vital need of thorough work in this fleld.

Here, as elsewhere, prostess has marked the filght of time. Today people are interested in public health service as never before. It is the exceptional physiclan now who is not awake to his duty in these matters, and in a number of countles they are supporting their Health Officers right royally. The Health Officers, most of them, though salaries are still Inadequate, are sensible to their duties and endeavoring to perfect the work.

This work is not child's play, it is not an ephemeral work, it is not a work devold of value. Gentlemen, it is a man's job; it is an enduring work. Certainly it is patent to every intelligent physician in the State of Alabama. And it is to be hoped that they, the physiclans, will enlighten the public and use their Influence to gain the sup. port of the public throughout the entire State.

What are some of the requisites of a good Health Officer-his earmarks, so to speak?

Above all things he should love his work, be interested in it and realize it as a vital work. He must be consclentious; he must know that duty is inexorable and on no account whatever is it 
to be neglected or dlsregarded. He must be intelligent and alive to every forward step in thls feld. He must be a man with iron in him, at least half a backbone. Courage is as essential here as in other fields of labor. He must possess tact, diplomacy, patience, and willingness to persevere: not to let up in his efforts so long as he holds the offlce. Eternal endeavor is the price he must pay for guccess.

Agaln, he must be courteous in his dealings with the physiclans, midwives and undertakers. We need often to give heed to the old Spanish proverb, "A man may go through the world with his hat in hls hand."

Given such Health Officers as have been described here, in a short time every county in Ala. bama will be reporting 90 per rent of her births and denths, and there will be a shrinkage in the death rate and decided lowering of the mortality rate from communicable diseases. Our records will be continuous and complete.

As snnitation in its broadest sense is understood and practiced. our people will be happler and will have dollars as well as years as their heritage.

Just here permit me to say that in choosing such a Henlth Officer the society should fix his term of office for not less than four years, and when a cood man has been obtained he should be retained. for trequent changes interrupt the work, the records suffer and become less valuable.

The public must have a complete and continuous record for them to thoroughly apprecinte its value. Wherever feasible the city and county work should be combined. You thus load one man with all the responsibility and the compensation is better.

The present Health oncers should demonstrate to the public the need and value of this work by their fidelity and in time the compensation will be sufficient to allow a mnn to devote his whole

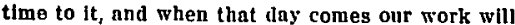
compare favorably with that of the old countries, where for decades their work, especially the collection of statistics, has so far excelled ours.

In reading the public health laws of Alabama we gather that the chief duties of a County Health Ofifcer are comprehended under three heads. namely: The collection and registration of vital and mortuary statistics, a general oversight of the sanitary condition, and a control of the com munlcable diseases, the prompt and proper reporting to the State Health Officer, the County Medidal Soclety and the Court of Counts Commisstoners.
In pursuing this work to a successful end he must have a united and harmonjous medical soclety to sustain him. The parent, the creator, must be interested in the work and ultimate success of the child and creature. Each must understand and perform their reclprocal cutles. The soclety ought to show Its appreciation of falthful eervice, and be ever ready to sustaln their coefficient. To refrain from throwing brick. bats is good, but to shower roses ts tar better. It is one of the duties of the society to see that their Health Officer does his duty.

The Health Officer should consult with them as to methods and measures used: they should give advice, but be careful not to fetter hIm with too much advice or needless instructions.

Just criticism of his actions, niade privately, does good, and occasionally, very occasionally. however, public criticlsm may do good. Caution is needed at this point. Give to your Health Officer credit for common sense and a fair meas. ure of good judgment; be charitable and keep sllent as long as the public weal will permit before resorting to this keen instrument.

Again. let me say, when a soclety finds a man is doing good - work and is thoroughly acceptable to the Commisisoners and public generally, do go slow in making a change. 'Tis a plty we cannot hare this work. under a clvil service plan, as tre quent changes are certainly hazardous.

In a word, there should be mutual respect and esteem and a hearty co-operation between these two forces of our public health service.

What methods are to be pursued to secure prompt reports from doctors, midwlves and under takers? In beginning his work, the Health Officer should secure from his predecessor as complete list as possible, supplement this by writing to at least two men of note in each beat asking for a list of evory doctor, midwlfe and undertaker in their vicinity. Again, write each doctor 'for such a list, arrange this list alphabetically under physiclans, midwives and undertakers. On the left of each list place ther address of each person. On the right rule off twelve spaces and opposite each name draw a line horizontally across the twelve spaces, dividing each Into traives. You now have a record for twelre monthis. In the upper division opposite each name a space is left for the letter R. (reported) or D. (delinquent); whlle the lower space is for the day the report is recelved:

Send a revised list to the State Health Officer. asking : that these people be furnished as soon as posslble with their yearly supply-of bjanks; 
asking for a supply for yourself in case of an emergency.

Now, then, write each of your doctors, midwlves and undertakers, telling them of your desire and determination to do your duty, reminding them of theirs as laid down by the Alabama Code, and urging full and prompt reports each month. A trip through the county to meet these parties 18 better. You thus gain that personal touch that is so often necessary In dealing with people.

Let each one know that they are a unit in this work and that their part must bo done to insure success and that to ench of them will come a meed of pralse.

After thus organizing the work, and that is reaily the most important part of all, if you find forgetful ones, careless ones, write them a post card between the first and fifth of each month, reminding them and telling them how your work is hindered by their delinquency or tardiness. Make use of the telephone and when possible speak to them personally. In doing theso things-the writing, the telephoning and personal interviews-be courteous, yet dignitied, but not Imperious. Let them understand it is a work for thelr fellow-men and thelr chlldren; touch their pride; stir up loyalty as you compare the work in other counties. Be patient, control your temper, keep doggedly on sour job.

Such a courge is not advised ad infinitum. There may come a time when the Iron in you will have to assert itselt. At this point write agaln and say the law must and shall be entorced unless there is a speedy compliance. Tell them they are bring. ing down upon their own heads retribution well deserred. After this, if there is sllence one course alone is left-the reporting to a County Judge or Justice of the Peace. When the case comes to Issue, be there with the record above referred to to substantiate jour case. Ask for the lowest fine and after this treatment the chances are, ninety-nine cases out of a hundred, you will not have to repeat the dose or even agitate the bottle. Some affectlons are hard to cure, or it may be it is the Individual. If you have this kind of a case, where revenge or obstinancy manifest them. selves, repeat the dose, only asking for the largest fine that can be administered, and, gentlemen, your patient is a well man and will sin no more, even though he fall to hold you in loving remembrance. Bear in mind, plense, these two latter methods are dernier resorts. Persilstency, tact, and gentleness, all of these before the harsher method.

What of the relation of the public to the County Health Officer?
Included in the public are, of course, the Counts Commissioners, who hold the purse strings. It takes money to do this work well and we mugt get the public ear and confidence. A Health Officer who pursues the course as outlined above will win the confidence of the publla. The people have a vital interest in this work, and as they do the paying, they certainly deserve consideration. The county society should elect a man to ofitce who is acceptable to the Board of Commisisoners.

When this course has been followed, a man who is acceptable, a man in whom they have con. fdence, when such a mall appears before the board they are ready to listen and pay the bills. The relation in a measure is that of employer and employe.

Public sentiment, nublic interest ought to be so strong as to compel a Health Oficer to discharge his duty. The public should look upon thls officer not as one who curbs thelr liberties and saps, as a parnsite, their monoy, but ratber as a frlend and $a$ benefactor to the whole county.

How to arouse public sentiment as to the execu. tion of public health laws?

Dispel Ignorance by the diffusion of knowledge. Get the papers to be your ally. Write articles on public lienlth questions and tho laws pertaining thereto. Let the people know that this work when done well will put dollars In their pockets, roses on their cheeks, songs in thair hearts and add years to their pilgrimage on mother earth. Let them know their respresentatives made these laws and they are for their wellare.

Seize every opportunity to speak to the scholars and public on these questions, let them know they have a part in the work. Exhibit the fruits of your mutual labors, and lo, you have the people with you In this noble work. As to the control of communlcable diseases, tact, Intelligence and courage will win.

As to sanitation, every Health Oficer shodid labor to minimize mosquito production. Ponds. and pools of stagnant water are fearful blights on a State; each year malaria swells the death rate and incapacitates thousands of our citizens. Ho should labor to have all people enjoy wholesome water. He should establish the sanitary closet throughout his county as rapidly as possible. He should preach, so to speak, from the hilltops good hygienle hablts in all people.

Lastly, but very important indeed, report prompt. ly and fully each month, and at the end of esch. year.

In conclusion, let me repeat, a love of the work, a keeping abreast of the times, a conscientions 
ness In the work. tactfulness, civility, alertness, courage, and perseverance are the personal elements entering into your success. The support of your County Medical Society, the respect and confidence of the public that bas become Intelligent upon public health questions, are the remain. Ing elements that enter into your success as a County Health Officer in this State. A conscious. ness of duty well done, a realization of benefits conferred on your contemporaries, and blessings on posterity will bring to you a recompense far exceeding any monetary ralue.

\section{CARUIOPTOSIS-REPORT OF CASE.}

By Dr. P. T. Fleming. Enterprise, Ala.

Cardioptosls (traunuatic origin) of geven sears' standing.

History-White, male, farmer, age 53; always been stout and healthy until he recelved an in. Jury seven years ago. Been a hard laborer all his life.

How Injured-He was fixing to prize up a $10 \mathrm{~g}$ and had a sixteen-foot pole on his right shoulder; the front end of the pole was under the $\log$, the pole being held at angle of about 45 degrees, when it slipped from under the $l o g$ and fell to the ground with considerable force, knocking him backwards to the right. But he caught to a stump with his left hand and did not fall to the ground. The blow was severe, and according to bis statement, his heart was displaced upwards at least two inches, and remained there three or four minutes, during which time it took a great effort for him to breathe. At the expiration of three or lour minutes from the time of the accident, with some assistance. he raised up on hls toes and then came suddenly down on his heels, with knees stiffened. He telt hls heart come down some with the first jolt, and repeating the process three or four times, brought the heart down to Its normal position; but, instead of stopping when it reached its normal place, it continued to descend (without any more jolting) untll it cane about two fuches below the normal. After this he walked half a mile to his home, and, strange to say, he did not stop golng about a single day, burt did no work tor several weeks. He spat up blood for three or four days after the Infury, and was very weak and nervous. He did hot have a physiclan with him at this time. He was very reak for several weeks, but gradually improved untll finally be could resume a part of his labors.

Present Conition-When standing or walking, bis heart descends too low. Stays in normal position when sitting up and leaning a little torward; also when lying down with head and shoulders slightly elevated; but if he lies with head and shoulders below a level with the body, the heart goes about two Inches too high 11 . He wears a belt (qulte tight) close up under the ribs, which holds the heart up lairly well, and enables him to walk and work with comparative comfort. When lying down his heart beats slowly ( 40 to 60 per minute), but about normal when sitting or standing. No valvular lesions are found, and no intermissions. Kidneys are normal; appetlte good; digestion not so good as before the injury; bowels a little Inclined to be constipated.

He does quite a lot of plowing and blacksmith work. Can't do any kind of work that requires" stooplng or heary lifting. If he works hard all day, he cannot lle cown at night; has to sit in rocking chalr to sleep; but if he does not exert himself too much, be can lie down at night and sleep well. Ordinarlly, be sleeps well, unless he exerts himself through the day. When his heart gets too high or too low it makes him nervous and cauges dyspnoea. He cannot run or take any other violent exercise. Cannot take alcohol in any form. When be takes things quiet and easy. he is comfortable, and gets along nfcely. He has chronic appendicitis of a mild type. Otherifise hls general health is good.

\section{THE PROPAGATION OF TERTIAN MALARIA IN THE MOUNTAINS OF NORTH CARO. LINA, HENDERSON COUNTY IN PARTICULAR.}

By W. B. W. Howe, M.D., Hendersonville, N. C.

Those who have had tIme, and to whom It has occurred to lonk into the subject for themselves, may find little of interest in what follows. But It is to others that it is hoped these notes may be worthy of some consideration.

Whether the apparent pureness of our mountain air, the bracing qualities of our climate, the assumed infrequency of mosquitoes, or the fact that numbers slck with malarla come to recuperate from unhealthy regions along our coast-whether the foregoing or other incidents account for tho prevalent impression that malaria is not propa. 